\title{
Predicting adaptation to presymptomatic DNA testing for late onset disorders: who will experience distress?
}

\author{
A C DudokdeWit, A Tibben, H J Duivenvoorden, M F Niermeijer, J Passchier, and the \\ other members of the Rotterdam/Leiden Genetics Workgroup ${ }^{\star}$
}

\section{Department of}

Medical Psychology

and Psychotherapy,

Erasmus University

Rotterdam, PO Box

1738, 3000 DR

Rotterdam, The

Netherlands

A C DudokdeWit

A Tibben

H J Duivenvoorden

J Passchier

Department of Clinical Genetics, Erasmus

University and

University Hospital

Dijkzigt, Rotterdam,

The Netherlands

A Tibben

M F Niermeijer

Department of Clinical Genetics, University

Hospital Leiden, The

Netherlands

A C DudokdeWit

*Participating in the Rotterdam/Leiden Genetics Workgroup, besides the authors already mentioned, are: $\mathrm{D}$ Lindhout, $\mathrm{E} \mathrm{J}$ Meijers-Heijboer, P G Frets, Department of Clinical Genetics, Rotterdam; P G

Frets, L N Lodder, R W

Trijsburg, $M$ W Zoetewij,

Department of Medical

Psychology and

Psychotherapy, Rotterdam; J

G M Klijn, Daniel den Hoed

Cancer Centre, Rotterdam;

A Bröcker-Vriends, A van

Haeringen, A T J M

Helderman, $Y$

Hilhorst-Hofstee, S Kant, J A

Maat-Kievit, J C Oosterwijk,

$J J$ van der Smagt, $M$

Vegter-van der Vlis, M-A C S

Vries-van der Weerd, $M$ W

Zoeteweij, Department of

Clinical Genetics, Leiden; E

Bakker, P Devilee, $M$

Losekoot, C Tops,

Department of Human

Genetics, Leiden; C J

Cornelisse, Department of

Pathology; H F A Vasen,

Dutch Foundation of

Hereditary Tumours, Leiden.

Correspondence to:

Dr DudokdeWit, Rotterdam.

Received 28 February 1997 Revised version accepted for publication 13 February 1998

\section{Abstract}

The first comparative study on predicting post-test distress (conceptualised by intrusion and avoidance, measured with the Impact of Event Scale) after presymptomatic genetic testing for Huntington's disease (HD, $n=25)$, cancer syndromes (familial adenomatous polyposis (FAP, $n=23)$ ), and hereditary breast and ovarian cancer (HBOC, $n=10)$ is reported.

The variables with the highest predictive potential of post-test distress are presented. Participants who were depressed before the test were more distressed after testing, but we found that those who were anxious before the test were less distressed, that is, had less intrusive thoughts post-test. Other factors associated with a higher level of post-test intrusion were gender (being a woman), having children, and pre-test intrusion. Religion and being at risk for $\mathrm{HBOC}$ were associated with less post-test intrusion. Participants who showed avoidance behaviour before the test and those who had many people available for support showed more avoidance behaviour post-test.

The test result did not additionally contribute to post-test distress. The prima facie simple notion that the test result, as such, determines the distress experienced seems to be a misrepresentation of the complex reality.

$(\Im$ Med Genet 1998;35:745-754)

Keywords: presymptomatic DNA testing; predicting distress; hereditary late onset disorders

Predictive testing is now available for several autosomal dominant heritable disorders with different disease characteristics (for example, age of onset, (in)complete penetrance, (no) treatment options, etc) including Huntington's disease (HD), myotonic dystrophy (MD), hereditary cerebral haemorrhages with amyloidosis-Dutch type (HCHWA-D), familial Alzheimer's disease, hereditary breast and ovarian cancer (HBOC), familial adenomatous polyposis (FAP), hereditary non-polyposis colonic cancer (HNPCC), and multiple endocrine neoplasia type $2 \mathrm{~A}(\mathrm{MEN}-2 \mathrm{~A})$. $^{1-11}$

The psychological implications of predictive testing for Huntington's disease (HD) have been described in several studies. ${ }^{12-23}$ Catastrophic events have, fortunately, only occasionally been observed, as was confirmed by the Vancouver group in a world wide survey. A total of 107 centres from 20 countries provided data from 5781 subjects who had received results since the advent of testing. Most catastrophic events occur within one year after the test result; five subjects committed suicide and 16 attempted it. ${ }^{12}$ In general, however, carriers were reported to show relief from previous psychological distress and a tendency to minimise the impact of the test result on their future. A substantial number of non-carriers experienced no relief, numbed emotions, survivor's guilt, and difficulties in developing a new life perspective. ${ }^{1821}$

For the cancer syndromes, predictive testing was generally found to be well received by both patients and families at risk for FAP; carriers for HBOC and non-carriers showed consistent reduction in distress and impairment post-test. ${ }^{24-39}$

In a previous comparative study on predictive testing for $\mathrm{HD}, \mathrm{FAP}$, and $\mathrm{HBOC}$ we found that the course of distress through time reported by the participants at risk is similar. However, participants tested for HD reported more distress than those tested for FAP or HBOC. Also women tended to report more distress than men. ${ }^{40}$

The majority of these studies only described the psychological impact of predictive testing in general. For clinical practice, however, is it important to identify those participants who may need additional support to prevent maladjustment after testing. Only three studies identified pre-test predictors of psychological adaptation after predictive testing for $\mathrm{HD}$. $^{16}{ }^{41-43}$

Tibben et $a l^{41}$ found that distress before the test was associated with post-test distress. Distress among carriers was more often found to be associated with post-test intrusion than distress among non-carriers. Participants who avoided HD related situations post-test often had only recently learned about $\mathrm{HD}$, were less satisfied with the available support, and at the same time more optimistic about the future. In general, high post-test distress was equally found among both carriers and non-carriers of the HD gene. ${ }^{42}$ Decruynaere et $a l^{16}$ reported that less post-test anxiety was associated with more ego strength in combination with the ability to use comforting ideas as a coping strategy. Post-test depression was found to be associated with pre-test depression, and more post-test ego strength was associated with more ego strength pre-test, all independent of carrier status. Codori et $a l,{ }^{43}$ however, reported that 
Table 1 Autosomal dominant heritable disorders included in this study

\begin{tabular}{|c|c|c|c|}
\hline & $H D$ & $F A P$ & $H B O C$ (caused by the BRCA1 gene) \\
\hline Age of onset & $40 \pm 12$ years & From 12 years onwards & From 25 years onwards \\
\hline Disease characteristics & $\begin{array}{l}\text { Involuntary movements, changes in behaviour } \\
\text { and personality, cognitive impairment }\end{array}$ & $\begin{array}{l}\text { Development of numerous (at least } 100 \text { ) } \\
\text { colorectal polyps and multiple extracolonic } \\
\text { symptoms }\end{array}$ & $\begin{array}{l}\text { Breast and ovarian cancer for women, } \\
\text { possible colonic cancer for both men } \\
\text { and women, possible prostatic } \\
\text { carcinoma for men }\end{array}$ \\
\hline Duration of the illness & \pm 15 years & Variable* & Variable ${ }^{\star}$ \\
\hline Surveillance & - & Colonoscopy, sigmoidoscopy, rectoscopy & $\begin{array}{l}\text { Breast examination, palpation, } \\
\text { mammography, ultrasound screening, } \\
\text { etc }\end{array}$ \\
\hline Treatment modalities & - & Colectomy & $\begin{array}{l}\text { (Prophylactic) mastectomy/ } \\
\text { oophorectomy }\end{array}$ \\
\hline Degree of penetrance & $100 \%$ (lifetime) & $100 \%$ (by age 40 ) & $95 \%$ (lifetime) \\
\hline
\end{tabular}

$\mathrm{HD}=$ Huntington's disease; $\mathrm{FAP}=$ familiar adenomatous polyposis; $\mathrm{HBOC}=$ hereditary breast and ovarian cancer.

$\star$ Duration of the illness depends on the succes of the treatment.

those less well adjusted had proven to be gene carriers, were married, had no children, or were closer to their estimated age of onset.

The present report explored which pre-test variables (for example, distress, psychological, biographical, and medical variables) would have the highest predictive potential of posttest distress. The stress response theory of Horowitz et $a l^{44}$ involves alternating phases of intrusive thoughts and feelings and avoidance of feelings or situations related to a stressful event, in this study the genetic disorder. Intrusion and avoidance may alternate according to the person's idiosyncratic pattern until a period of working through occurs. ${ }^{45}$ The Impact of Event Scale (IES) ${ }^{44}$ permits careful and systematic evaluation of the stress responses that follow traumatic events by assessing the amount of intrusive thoughts and feelings and avoidance over the past week. We present predictors of distress, as measured with the two subscales (intrusion and avoidance) of the IES, after presymptomatic testing for $\mathrm{HD}, \mathrm{FAP}$, and HBOC. As potential predictors of post-test distress, the test result, the type of disorders, biographical data, social interaction measures, and psychological variables were taken into consideration.

This study is a part of a longitudinal follow up study on predictive testing focusing on: (1) the adjustment of people at risk and their partners after the DNA test results, and (2) identification of psychological determinants of adjustment problems after test disclosure. Our aim is to facilitate early detection of those at risk of maladjustment to a test result.

\section{Subjects and methods} PARTICIPANTS

Predictive DNA testing and psychological follow up were offered to people at $50 \%$ risk for $\mathrm{HD}, \mathrm{FAP}$, or HBOC, who were over 18 years of age. The inclusion criteria for the psychological study were an ability to give informed consent and adequate understanding of the questionnaires.

All genetic disorders in this study show autosomal dominant inheritance; the main characteristics are given in table $1 .^{46-51}$ The DNA mutation analyses used have been described elsewhere. ${ }^{52}$

Between September 1993 and August 1995, 137 subjects at risk for $\mathrm{HD}(\mathrm{n}=47)$, FAP $(n=60)$, and HBOC $(n=30)$ who met the crite- ria were asked to participate in the psychological study. Before receiving their test result, 14 subjects at risk for either $\mathrm{HD}, \mathrm{HBOC}$, or FAP withdrew from the predictive testing procedure because they did not want the predictive test (yet). Twenty-three subjects, of whom 16 were at risk for FAP, opted for the DNA test but decided against the psychological study. Another six, who initially consented to participate, did not return their pre-test questionnaires. Three participants at risk for FAP did not receive a test result as neither mutation nor linkage analysis was possible and were lost to follow up. ${ }^{53}$

Ninety-one subjects at risk for HD, FAP, or HBOC did participate in the psychological follow up study while receiving their test result. After the test result, 33 participants withdrew from the follow up appointments (five kept postponing appointments, eight found talking too difficult, 10 found talking unnecessary, and 10 did not return their questionnaires). These drop outs had a higher education than those continuing the psychological follow up study, as has been described elsewhere. ${ }^{40}$ Finally, 58 people at risk completed the follow up period of six months, 25 at risk for $\mathrm{HD}, 23$ at risk for FAP, and 10 at risk for HBOC. Data on the test candidates are given in table 2 .

More women $(n=36)$ than men $(n=22)$ participated in this study; 20 subjects were identified as gene carriers and 38 as non-carriers. One of the three women who were identified as gene carriers of the BRCAl gene, causing HBOC, opted for prophylactic mastectomy first and a prophylactic oophorectomy at a later stage after oncological counselling. Another woman opted for a prophylactic oophorectomy and regular screening of her breasts. The third woman opted for regular screening before deciding upon prophylactic surgery. Gene carriers of the polyposis gene continued or resumed screening. We found that participants at risk for FAP were younger, more often single, without children, and more often practising a religion.

\section{PROCEDURES}

Information about the availability of the DNA test was given by the general practitioner, neurologist, oncologist, clinical genetic service, relatives, or one of the respective patient organisations. Families who participated in the research phase of the linkage study of the cancer syndromes were informed about the 
Table 2 Pre-test data on the 58 participants in psychological follow up study

\begin{tabular}{lllllll}
\hline & $H D(n=25)$ & $F A P(n=23)$ & $H B O C(n=10)$ & Statistic & $d f$ & $p$ \\
\hline Male/female at risk & $11 / 14$ & $9 / 14$ & $2 / 8$ & $\chi^{2}=1.77$ & 2 & 0.41 \\
Gene carrier/non-carrier & $9 / 16$ & $7 / 16$ & $4 / 6$ & $\chi^{2}=0.22$ & 2 & 0.87 \\
Age (y), mean (SD) & $39.5(11.5)$ & $28.6(9.1)$ & $42.6(6.3)$ & $\mathrm{F}=6.77$ & 3.57 & $<<0.001$ \\
Married/common law & $17(74 \%)$ & $8(38 \%)$ & $10(100 \%)$ & $\chi^{2}=12.8$ & 3 & 0.005 \\
Child(ren), No (\%) & $13(52 \%)$ & $7(30 \%)$ & $9(90 \%)$ & $\chi^{2}=21.5$ & 6 & 0.044 \\
Practising religion, No (\%) & $5(20 \%)$ & $8(34.8 \%)$ & $2(20 \%)$ & $\chi^{2}=6.86$ & 2 & 0.032 \\
Education, No (\%) & $7(28 \%)$ & $3(14 \%)$ & $5(50 \%)$ & $\chi^{2}=5.9$ & 6 & 0.43 \\
$\quad$ Low & $13(52 \%)$ & $15(72 \%)$ & $4(40 \%)$ & & & \\
Middle† & $5(20 \%)$ & $3(14 \%)$ & $1(10 \%)$ & & & \\
Highł & & & & & & \\
\hline
\end{tabular}

$\mathrm{HD}=$ Huntington's disease; $\mathrm{FAP}=$ familiar adenomatous polyposis; $\mathrm{HBOC}=$ hereditary breast and ovarian cancer. *Elementary school and low vocational school.

†High school, secondary school, or secondary vocational school.

$\ddagger$ High vocational school, university, or college.

df, $F, \chi^{2}$, see text for details.

possibility of predictive testing by the Department of Clinical Genetics in Leiden and Rotterdam or by the Dutch Foundation for Hereditary Tumours. Information from the public media made a number of participants aware of the autosomal dominant inheritance of the disorders in their family.

The study protocol was adapted from the HD protocol..$^{54}$ The genetic counselling and the psychological study were conducted at the Departments of Clinical Genetics of the University Hospital Leiden and the University Hospital Dijkzigt, Rotterdam, from September 1993 to September 1995. Two pre-test and two post-test sessions were held with the psychologist (ACDdW). At the first session (at the Department of Clinical Genetics) the psychological study was introduced. Subsequently, psychological self-report inventories were handed out to the participants at risk and their partners (baseline). One month later at the second session (at the same department), blood samples were taken by the clinical geneticist when participants wanted actual testing. Also, the participants at risk and their partners had separate interviews with the psychologist. After six to eight weeks the participants were invited to receive their test result. Follow up interviews, similar to the interview after blood sampling, were conducted approximately one week and six months after the test result. The interview results are used here for the interpretation of the questionnaire results in the present study. They are more extensively described elsewhere. ${ }^{55}$

The self-report inventories given before the test included the Impact of Event Scale (IES), the Beck Hopelessness Scale (BHS), the Hospital Anxiety and Depression Scale (HAD), the Symptom Checklist (SCL-90), the Social Support Questionnaire, the Loneliness Scale, and the Family Dimension Scale (GDS) (see below). Six months after the test result the IES, among others, was again handed out to the participants.

\section{QUESTIONNAIRES}

Predictor variables

Medical characteristics: DNA test result and the type of disorders, obtained from medical files.

Biographical data: gender, age, religion, marital status, and having children or not, obtained by questionnaire.
Social interaction measures (assessed before the test): loneliness was measured by the Loneliness Scale of De Jong-Grierveld and Kamphuis. ${ }^{56}$ The scale consists of 11 items; six are formulated negatively and five are formulated positively $(\min =0, \max =11)$. The five category responses for every question are transformed into dichotomous responses $(0$, 1). The scale assesses a continuum from severe loneliness to not being lonely.

To assess the access to supportive allies of participants at risk we used the six item Social Support Questionnaire (SSQ) developed by Sarason et al..$^{57}$ Each item has two parts; the first part of each item (SSQN) assesses the number of other persons that are available in times of need and includes questions like "Whom can you really count on to be dependable when you need help?" and "Who accepts you totally, including both your worst and your best points?". Subjects can indicate no-one, up to a maximum of nine persons $(\min =0$, $\max =54$ ). The second part of each item measures the degree of satisfaction with the perceived support (SSQS). Subjects can indicate how satisfied they were on a six point Likert scale from "very dissatisfied" to "very satisfied". All scores are added and divided by six $(\min =1, \max =6)$.

Family functioning was assessed by the Dutch adaption of the Family Adaptability and Cohesion Evaluation Scales (FACES) of Olson et al,$^{58}$ the Family Dimension Scales. ${ }^{59}$ Subjects had to indicate whether items such as: "At home we always ask each other for help; Every decision is made with the whole family; We are used to taking care of our own matters at home" were "never true" or "always true" on a four point Likert scale. The scale has three subscales, cohesion (the commitment experienced towards other family members), adaptability (the flexibility of power and role structures within the family, as a reaction to external and internal stressors), and social desirability (the family representation). Each subscale is divided into four levels, which are curvilinear. Families scoring in the middle are considered as optimal and on either extreme of each scale as dysfunctional. ${ }^{59}$

Psychological measures (assessed pre-test): psychological distress was measured using the Impact of Event Scale (IES). The IES classifies the effects of stress into two major categories: 
Table 3 (A) Mean and standard deviations of the social interaction measures and the psychological variables, before and after testing. (B) Correlations between the predictor variables and the outcome variables intrusion and avoidance in the group tested for Huntington's disease, familial adenomatous polyposis, or hereditary breast and ovarian cancer

\begin{tabular}{|c|c|c|c|c|c|c|}
\hline \multirow[b]{2}{*}{$A$} & \multicolumn{2}{|l|}{$H D$} & \multicolumn{2}{|l|}{$F A P$} & \multicolumn{2}{|l|}{$H B O C$} \\
\hline & Mean & $S D$ & Mean & $S D$ & Mean & $S D$ \\
\hline \multicolumn{7}{|c|}{$\begin{array}{l}\text { Social interaction measures } \\
\text { Loneliness }\end{array}$} \\
\hline SSQS & 2.0 & 2.9 & 2.0 & 2.7 & 0.9 & 1.5 \\
\hline SSQN & 1.8 & 0.8 & 1.8 & 0.8 & 1.3 & 0.4 \\
\hline FF adhesion & 18.8 & 7.2 & 19.6 & 7.5 & 15.7 & 6.8 \\
\hline FF cohesion & 21.1 & 4.5 & 21.0 & 6.3 & 23.8 & 11.1 \\
\hline & 63.4 & 10.8 & 58.9 & 13.0 & 55.5 & 15.7 \\
\hline \multicolumn{7}{|l|}{ Psychological variables } \\
\hline Intrusion $\mathrm{T} 1$ & 8.4 & 6.0 & 4.4 & 5.6 & 6.3 & 4.5 \\
\hline Avoidance T1 & 7.2 & 6.6 & 3.7 & 5.7 & 3.2 & 4.2 \\
\hline Anxiety & 5.8 & 4.1 & 5.7 & 4.4 & 5.3 & 3.2 \\
\hline Depression & 3.0 & 2.6 & 2.2 & 2.2 & 2.4 & 2.7 \\
\hline Psychol complaints & 67.8 & 15.7 & 75.9 & 24.6 & 60.7 & 7.3 \\
\hline Hopelessness & 5.9 & 3.0 & 4.9 & 3.1 & 3.9 & 1.4 \\
\hline Intrusion $\mathrm{T} 4$ & 6.8 & 5.3 & 3.0 & 3.8 & 3.6 & 3.8 \\
\hline Avoidance T4 & 5.4 & 5.1 & 2.7 & 4.1 & 2.7 & 4.7 \\
\hline$B$ & \multicolumn{6}{|c|}{ Outcome variables } \\
\hline Predictor variables & Intrusion T4 & Avoidance T4 & Intrusion T4 & Avoidance T4 & Intrusion T4 & Avoidance T4 \\
\hline \multicolumn{7}{|l|}{ Medical } \\
\hline $\begin{array}{l}\text { Gene carrier/non-carrier } \\
\text { Biographical }\end{array}$ & -0.26 & -0.21 & -0.17 & -0.18 & 0.13 & -0.12 \\
\hline Male/female at risk & 0.26 & $0.41^{\star}$ & $0.53^{\star}$ & 0.38 & 0.46 & 0.26 \\
\hline Age & 0.23 & -0.01 & 0.32 & 0.10 & -0.33 & 0.18 \\
\hline Married/common law & 0.03 & -0.28 & -0.002 & -0.10 & 0.22 & 0.10 \\
\hline Child(ren) & 0.29 & -0.05 & 0.28 & 0.12 & 0.10 & -0.02 \\
\hline \multicolumn{7}{|l|}{ Social interaction measures } \\
\hline Loneliness & 0.20 & $0.48^{\star}$ & -0.24 & -0.14 & 0.26 & -0.26 \\
\hline SSQS & 0.03 & $0.40^{\star}$ & -0.23 & -0.09 & -0.04 & 0.55 \\
\hline SSQN & 0.01 & 0.14 & 0.19 & 0.18 & $-0.71^{\star}$ & -0.06 \\
\hline FF adhesion & 0.13 & 0.06 & 0.27 & 0.07 & -0.22 & -0.49 \\
\hline FF cohesion & 0.23 & 0.13 & 0.19 & 0.11 & 0.63 & -0.53 \\
\hline \multicolumn{7}{|l|}{ Psychological variables } \\
\hline Intrus $\mathrm{T} 1$ & 0.17 & $0.52^{\star}$ & 0.38 & $0.44^{\star}$ & 0.19 & -0.29 \\
\hline Avoid T1 & -0.004 & 0.27 & 0.32 & $0.42^{\star}$ & 0.10 & -0.03 \\
\hline Anxiety & -0.01 & 0.28 & -0.003 & 0.14 & -0.03 & 0.11 \\
\hline Depression & 0.32 & 0.30 & -0.16 & -0.11 & -0.06 & 0.03 \\
\hline Psychol Com & 0.27 & 0.16 & -0.05 & 0.11 & 0.07 & 0.20 \\
\hline Hopeless & 0.14 & 0.22 & -0.06 & 0.006 & 0.20 & -0.07 \\
\hline
\end{tabular}

$\mathrm{HD}=$ Huntington's disease; $\mathrm{FAP}=$ familial adenomatous polyposis; $\mathrm{HBOC}=$ hereditary breast and ovarian cancer; Int=Intrusion and Avoid=Avoidance are both measured with the IES; T1 before taking the test; T4 six months after receiving the test result; Anxiety and Depression are both measured with the HAD; Psychol Com=Psychological Complaints are measured with SCL'90; Hopeless=Hopelessness is measured with the BHS; Loneliness is measured with the Loneliness Scale; SSQS=satisfaction with social support, SSQ $N$ is the number of persons from which social support is received, both measured with SSQ; FF=family function, adhesion and cohesion are both measured with the Dutch adaptation of the FACES.

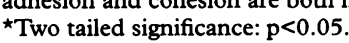

intrusion and avoidance. Intrusion refers to intrusively experienced ideas, images, feelings, or bad dreams. Avoidance refers to consciously recognised avoidance of certain ideas, feelings, or situations. ${ }^{4460}$ The IES is a reliable, selfreported scale that can be anchored to any specific life event. It permits assessment of subjects over time, comparison of the degree of distress among subgroups, and comparison of the impact of various life events. ${ }^{45}$ The IES was anchored to the disease in the family, either $\mathrm{HD}$, FAP, or HBOC. Items read like: "I thought about Huntington's disease when I didn't mean to" or "I avoided letting myself get upset when I thought about hereditary breast and ovarian cancer or was reminded of it". The IES consists of seven items that form the intrusion subscale (score range $0-35$, with a higher score indicating more reported intrusion) and eight items that underlay the avoidance subscale (score range $0-40$, with a higher score indicating more reported avoidance). The items are scored by choosing one of four indicators of occurrence of the specified event (never $=0$, seldom $=1$, often $=3$, and continuously=5).

Anxiety and depression were assessed with the Hospital Anxiety Depression Scale (HAD) ${ }^{61}$ which has 14 questions, half of which reflect anxiety and half depression. The answer options indicate intensity of the given mood. The sum of the person's scores gives an overall anxiety $(\min 0, \max 21)$ and depression $(\min 0$, $\max 21$ ) score. A score of 8 to 10 on either subscale is an indication of borderline anxiety or depression, a score of 10 or higher on either subscale is an indication of clinical anxiety or depression. Validity and reliability have been proven. ${ }^{62}$

Psychological complaints were assessed by the Symptom Checklist (SCL-90), using the subscales agoraphobia, obsessive compulsive behaviour, interpersonal sensitivity, hostility, sleeping problems, and the residual items. ${ }^{6364}$ The subscales anxiety and depression were deleted to prevent overlap with the HAD. The subscale somatisation was deleted to prevent over-reporting of symptoms of the specific 
familial disease. The resulting "psychological complaints" scale consisted of 52 items $(\min =52, \max =260)$. "Psychological complaints" was highly correlated with the original psychoneuroticism scale $(r=0.96, p<<0.001$, one tailed). On the SCL-90, patients rate the degree of distress they have experienced in the preceding week for each of the 90 items on a five point Likert scale ( $1=$ not at all, $5=\mathrm{ex}-$ tremely). Validity and reliability have been shown in the Dutch population. ${ }^{65}$

Pessimistic expectations concerning themselves and their future were assessed with the Beck Hopelessness Scale (BHS). ${ }^{66}$ The scale consists of 20 true-false items of which nine were keyed false and 11 were keyed true; each response was assigned a score of 0 or 1 . The total "hopelessness score" was the sum of the scores of the individual items $(\min 0, \max 20$, $0-3=$ normal, $4-8=$ mild, $9-14=$ moderate, and $\geqslant 14=$ severe hopelessness). ${ }^{66-68}$ Reliability and validity have been shown. ${ }^{66} 68$

Outcome variables: psychological distress (intrusive thoughts and feelings and avoidance of disease related feelings and situations) was measured using the Impact of Event Scale (IES) six months after the test result.

\section{Statistical analyses}

All data analyses were obtained using SPSS for Windows version 6.1 . To differentiate the three categories of genetic disorders with regard to biographical data and social interaction measures, one way analysis of variance for continuous data was applied. A chi square test was used for nominal data. The significance level was set at 0.05 , two sided. If the testing was statistically significant, post hoc comparisons between the three genetic disorders was done for continuous data according to Scheffés S method, and for nominal data Bonferroni's procedure was applied.

We present two different statistical models, first multiple regression analysis for the prediction of post-test intrusion and second multiple regression analysis for the prediction of avoidance behaviour. Both linear and logistic regression were evaluated in each case and the best predictor model was selected for reporting. We looked for the best fitting prediction model for each. As the distribution of the scores on the avoidance subscale could not be transformed to a normal distribution, we chose to dichotomise this outcome variable. We selected a clinical relevant cut off point, which in daily practice could be considered more than "average".

For each model we tested whether any interaction effects (for example, type of disorder by any of the other predictor variables, test result by a psychological variable) would contribute to a better fitting model for predicting post-test distress.

Every categorical predictor containing more than two categories was transformed into a dummy variable. The number of dummy variables equalled the number of categories minus one.
INTRUSION

In order to estimate the outcome variable intrusion, the method of multiple regression analysis, by a backward elimination procedure, was applied. The multiple correlation (MR) of the final model was used as a measure of a goodness of fit. Basically, this measure is the correlation between the actual and the predicted outcome variable. The squared value of MR (also called coefficient of determination) represents the variance explained by the regression model. The regression procedure was as follows: as a first step, all candidate predictor variables were entered into the regression model; next, step by step the candidate predictor variables were eliminated from the model if they were not significant at the 0.05 level (backward elimination). For the sake of simple interpretation and comparison of the importance of the predictor variables in the final model, the standardised regression coefficients and the standard errors of these coefficients were presented. The significance of the final model was tested by $F$ statistic and the significance level was set at 0.05 .

The nature of the psychological tests caused skewing in the distributions (normal population scores zero or near zero, other scores high). Therefore, raw scores were square root transformed in order to obtain normal distributions, which are paramount for multiple regression variance.

AVOIDANCE

For the dichotomised outcome variable avoidance, the method of multiple logistic regression analysis was applied. The maximum likelihood was used to estimate the parameters of the model. In order to estimate the relative importance of the predictor variables, these variables were standardised with the exception of the dichotomised predictor variables. The logistic regression coefficient can be interpreted as the change in the log odds of the dichotomised outcome variable corresponding with a one unit change in the predictor variable, while the values of the other predictor variables in the model remain unchanged. The antilog $B(\exp (B))$ indicates the change in the odds corresponding with a one unit change in the adjusted predictor variable. Model chi square, comparable to the usual $\mathrm{F}$ statistic for regression analysis, is used to estimate the significance of the model with the significance level set at 0.05 .

To test the adequacy of both methods of regression analysis, the following assumptions were checked: normality (normal probability plot), homoscedasticity (plot of standardised deleted residuals against predicted values), linearity (plot of standardised deleted residuals against predicted values), influential observations (Cooks distance, leverage SDBETA), and multicolinearity (variance inflation factor). It appeared that the final model met all these assumptions. $^{69} 70$ 
Table 4 Prediction of intrusive thoughts and feelings six months after predictive DNA testing

\begin{tabular}{|c|c|c|c|}
\hline & \multicolumn{3}{|c|}{ Intrusion * } \\
\hline & $B t$ & $S e B \ddagger$ & $p$ \\
\hline \multicolumn{4}{|l|}{ Type of disorder } \\
\hline At risk for $\mathrm{HBOCS}$ & -0.38 & 0.11 & 0.002 \\
\hline Biographical variables & & & \\
\hline Gender & 0.35 & 0.10 & 0.002 \\
\hline Having children & 0.34 & 0.12 & 0.01 \\
\hline Religion & -0.29 & 0.11 & 0.01 \\
\hline \multicolumn{4}{|l|}{ Psychological variables } \\
\hline Depression $\pi$ & 0.29 & 0.12 & 0.02 \\
\hline Anxietyf & -0.57 & 0.15 & $<0.001$ \\
\hline Intrusion at baseline $e^{\star \star}$ & 0.48 & 0.14 & 0.002 \\
\hline
\end{tabular}

*Multiple $\mathrm{R}=0.76, \mathrm{R}^{2}=0.57, \mathrm{~F}=7.44, \mathrm{p}<0.001$.

$+B=$ standardised regression coefficient.

$\pm \mathrm{SeB}=$ standard error of the standardised regression coefficient. $\$$ HBOC=hereditary breast and ovarian cancer.

IAssessed with the Hospital Anxiety and Depression Scale.

$\star \star$ Assessed with the Impact of Event Scale.

\section{Results}

DESCRIPTIVE

The means and standard deviations of the psychological variables pre- and post-testing and the correlations between predictors and outcomes in the three subgroups of participants are given in table 3 .

POST-TEST INTRUSIVE THOUGHTS AND FEELINGS Table 4 presents the variables that were associated with the level of intrusion, six months after the test result. Women tended to report more post-test intrusion than men. Parents reported more post-test intrusion than childless participants. Pre-test intrusive thoughts and feelings were associated with similar feelings post-test.

Pre-test depression was associated with more post-test intrusion, but pre-test anxiety, on the other hand, was associated with less intrusion after the test. At risk carriers for HBOC reported less post-test intrusion than those formerly at risk for HD and FAP. Less post-test intrusion was reported by participants with a religion, compared to those without a religious conviction.

POST-TEST AVOIDANCE OF FEELINGS AND SITUATIONS RELATED TO THE DISORDER

Table 5 presents the variables that are associated with post-test avoidance behaviour. Women showed more post-test avoidance of the disorder than men. Pre-test depression was associated with more post-test avoidance of the

Table 5 Prediction of avoidance of feelings and situations six months after predictive DNA testing

\begin{tabular}{|c|c|c|c|c|}
\hline & \multicolumn{4}{|c|}{ Avoidance* } \\
\hline & $B t$ & $S e B \ddagger$ & $\operatorname{Exp}(B) S$ & $p$ \\
\hline \multicolumn{5}{|l|}{ Biographical variables } \\
\hline Gender & 1.04 & 0.43 & 2.83 & 0.02 \\
\hline \multicolumn{5}{|l|}{ Psychological variables } \\
\hline Depressionף & 0.99 & 0.40 & 2.70 & 0.02 \\
\hline No of supportive persons available ${ }^{\star \star}$ & 0.75 & 0.39 & 2.12 & 0.06 \\
\hline Avoidance at baselinett & 1.09 & 0.43 & 2.98 & 0.02 \\
\hline
\end{tabular}

A logistics regression analysis was conducted upon the $\mathrm{z}$ scores of the variables in the equation for comparison of the betas in table 3 with those in table 4 .

${ }^{\star} \chi^{2}=20.68 ; \mathrm{df}=4 ; \mathrm{p}<0.001$

$+\mathrm{B}=$ logistic regression coefficient.

$\ddagger \mathrm{SeB}=$ standard error of the logistic regression coefficient.

$\int \operatorname{Exp}(B)=\operatorname{antilog} B$. \Assessed with the Hospital Anxiety and Depression Scale

$\star \star$ Assessed with the Social Support Questionnaire.

t†Assessed with the Impact of Event Scale. disorder. Participants with multiple supportive persons reported more avoidance than those having fewer supporters. Pre-test avoidance behaviour was associated with the same behaviour post-test.

\section{Discussion}

GENERAL CHARACTERISTICS

Like others, ${ }^{162} 43^{71}$ we found a higher ratio of non-carriers to carriers. Brandt $e t a l^{1}$ reported that the difference in the number of carriers and non-carriers of the HD gene was unlikely to be the result of chance. Prospective noncarriers may, as a group, function better and be more interested in scientific advances.

In the case of $\mathrm{HD}$, most subjects at risk came for the test when at the average age of onset. ${ }^{47}$ In the case of the cancer syndromes, most subjects at risk, included in the present study, came to be tested when they were older than the average age of onset. ${ }^{4872}$ Having lived this long without developing symptoms is indicative of a smaller risk of having inherited the gene. This might also explain why we found fewer carriers than non-carriers in the population studied.

PREDICTING DISTRESS AFTER PRESYMPTOMATIC DNA TESTING

The variables which, together, had the highest predictive potential of post-test distress are addressed separately in the following section, for the sake of the readability of the text. We want to refrain from drawing conclusions about particular variables but want to hypothesise about their possible meaning for clinical practice.

\section{Medical characteristics}

The test result. When we compared the course of distress for the three groups of disorders up to six months after testing, we found carriers of the disease genes to show unchanged levels of distress, while non-carriers showed the expected decrease. ${ }^{40}$ In the present study, we explored which variables had the highest predictive potential of the distress six months after testing. In agreement with two Huntington's disease studies, ${ }^{1642}$ we did not find that the test result contributed additionally to posttest distress in the two models found. In the model predicting post-test intrusion this was because of a negligible effect (the standardised regression coefficient, $\mathrm{B}=0.04$ ), in the model predicting post-test avoidance there is the possibility that this could also be the result of lack of power (the standardised logistic regression coefficient $B=0.69$ and the standard error of the logistic regression coefficient $\mathrm{SeB}=1.09$ )

Both test results have their impact on the life of the participants. Gene carriers have often been found to use denial as a coping strategy, ${ }^{2151}$ and non-carriers often experienced a lack of relief, had numbed emotions, suffered from survivor's guilt, or had difficulties developing a new life perspective..$^{1821}$ These different emotional reactions to either test result may explain why the test result, as such, is not found to be related to post-test distress. 
However, others did find an association between being a gene carrier and post-test distress. ${ }^{41}{ }^{43}$ What exactly contributes to posttest distress in some and not in others needs to be investigated further, as suggested by Codori et al. ${ }^{43}$

Type of disorder: $H B O C$. The participants at risk for HBOC had reduced post-test intrusive thoughts and feelings, independent of their post-test genetic status. Previous description of this group suggested that they might be a selfselected and highly motivated group, being the first to undergo the test. ${ }^{55}$ Similar assumptions were made about the first participants in the presymptomatic HD studies. ${ }^{14}$ Also these first families received extensive attention from the clinical researchers during all the years of linkage studies, which might have introduced a bias. $^{23}$

However, low post-test distress in identified HBOC carriers and non-carriers was unexpected and contradicted our clinical observations where we found that predictive testing provoked emotional reactions in different family members up to six months after testing. ${ }^{27}$ This observation may be explained as follows.

(1) Actual predictive testing, first by linkage and then by mutation analysis, was introduced cautiously. After informing people about the option of informative testing, a waiting period of four weeks elapsed before blood sampling for the actual presymptomatic DNA test was done. Most participants stressed their impatience during the interview. They had been waiting for a result for "so long" (the research phase for linkage). This long standing anticipation apparently had a positive effect on their subjective capability to cope with any test outcome. The implications of an informative test result might have been on their minds for a long time; on the other hand, the end of waiting for an informative test in itself might have generated relief. Additionally, after wishing and striving for a test result, adverse effects are likely to be ignored, as the burden of participation would otherwise not have been worthwhile. ${ }^{74}$

(2) The psychological study was often experienced as psychological assessment (for example, assessing their ability to handle the test outcome) with implications for further testing. One could speculate that reporting little distress may be interpreted as wanting to prove that testing ought to be continued. Similarly, in the first family to be tested for HBOC in The Netherlands, "the example", the first person to be presymptomatically tested, felt a responsibility to reduce the fear in relatives and consequently did not report her own fears. ${ }^{27}$ Those to be tested in the future will be less tempted to under-report fears because they will no longer be pioneers.

(3) Shedler et $a l^{5}$ indicated that low scores on "mental health scales" may reflect opposite conditions. Low scores usually indicate no complaints, but they may also result from denial so as to "maintain an illusion of not being distressed". This is also shown in a comparative study on questionnaires and interview results, assessing the distress experienced before predictive testing for late onset disorders. ${ }^{55}$

(4) The options for preventive treatment in HBOC, although drastic, may offer some feeling of control in identified gene carriers and give a feeling of self determination. However, the options as such may also provoke distress.

\section{Biographical variables}

Women. As expected, women tend to report more post-test intrusive thoughts and feelings and avoidance behaviour about the disorder than men. ${ }^{40}$ Other studies confirm that men may have a greater tendency to deny their feelings ${ }^{76}$ and may be less able to face their fear and the implications of testing. ${ }^{26} 77$ Overall, more women come for predictive DNA testing which is also explained by their role of care giver and their involvement with childbearing. ${ }^{42} 7778$ After being identified as a gene carrier their worries will concern "who will take care of the children and keep the family united?"22 Female non-carriers often take on worrying tasks caring for affected relatives. ${ }^{1879}$

However, Codori et $a l^{43}$ in their Huntington's disease study, found no difference between men and women and attributed this to the fact that participants asked for the information they received. Further research is needed to clarify the factors that contribute to the difference in distress between men and women.

Children. Giving information to offspring was often a motive to be tested ${ }^{52}{ }^{70-83}$ and having children was experienced as an additional stressor during testing. ${ }^{22} 8485$ In the semistructured interview with the psychologist (ACDdW), participants expressed their concern about becoming ill in the future. Above all, however, it was found almost unbearable that they might have transmitted the disorder to their children. Both carriers and noncarriers were still dealing with these emotions six months after testing.

Codori et $a l^{43}$ reported that childless participants were found to be less well adjusted after testing. The percentage of parents in the present study and in the study of Codori $e t a l^{43}$ is similar ( $50 \%$ and $48 \%$, respectively). An explanation for the difference between the two studies might be that in the study of Codori et $a l$, subjects at risk were determined to refrain from having children after they had proven to be gene carriers. The existential gap of not leaving something of yourself to this world while at the same time knowing that life might be short is distressing. In the present study, particularly participants at risk for cancer considered an unfavourable result no reason to refrain from having children. The subsequent worry about their offspring is then experienced as distressing.

Religion. Church attendance and clerical attention may function as a source of support. ${ }^{86}$ Faith may also give guidance in questions on the meaning and essence of life, such as "why (not) me?"86-89 


\section{Social interaction measures}

Social support. Contrary to what would be expected, we found that those with more people to support them before testing showed more avoidance post-test. However, looking closer at the items on the avoidance subscale makes this easier to understand. The avoidance subscale of the IES consists of items such as: "I avoided letting myself get upset when I thought about the disorder or was reminded of it; I stayed away from things or situations that might remind me of the disorder; I tried not to talk about the disorder". One way to explain this behaviour is seeking company as a form of distraction. On the other hand, having more people for support may also indicate that a participant has to tell his/her story more often, and subsequently finds him/herself to be occupied by the disorder more often. The attention can be experienced as overattention stimulating avoidance behaviour.

\section{Psychological variables}

Intrusive thoughts and feelings. Pre-test intrusive thoughts and feelings were associated with similar feelings post-test. Tibben $e t a l^{41}$ found this for carriers of the HD gene, but not for non-carriers. In non-carriers they found less intrusive thoughts and a sustained emotional numbness. In the present study, many noncarriers were informed that depressed emotional feelings were a normal post-test reaction. ${ }^{1873}$ Patient organisation brochures have also addressed this point. Non-carriers learned how the burden of the disease might have prevented them from dealing with the emotions of contact with affected relatives, both before and after testing. We speculate that such information set in motion the working through of the scenario of a "favourable" test result. This might explain the differences between the results of the present study and those reported by Tibben et al. ${ }^{41}$

Avoidance of feelings or situations. Like Tibben et $a l_{,}{ }^{41}$ we found that the avoidance behaviour before the test among carriers and non-carriers was associated with post-test avoidance behaviour. The problems related to the disorder seem to continue independently of the test result. Non-carriers may have experienced a shift of focus, first facing the threat of being a gene carrier and post-test the care of affected relatives, unresolved memories concerning the disorder, and feelings of guilt. ${ }^{18}{ }^{73}$ Additionally, carriers may experience that the relief of knowing becomes overshadowed by the fear of developing the disease.

Depression. Depression before testing was associated with considerable distress (for example, intrusion and avoidance) post-test, which is similar to the findings of Decruyenaere $e t a l^{16}$ for HD. Pre-test depression seems to interfere with preparation for the possible test result. Lack of preparation may result in post-test avoidance of ideas, images, and feelings they intrusively experience. This pattern may reflect problems in adjusting to the effects of the disorder on their life and needs attention.
Anxiety. Severe anxiety before the test predicts less intrusion, which may represent "work of worrying", ${ }^{90}$ helping the participant to work through their anxiety and grief and to cope effectively with the subsequent crisis. On the other hand, less intrusion can also be interpreted as the result of the need to undo the impact of testing. As the test result cannot be undone, personal disintegration can sometimes only be prevented by undoing the psychological impact of the test.

\section{Interaction effects}

We did not find that interaction effects (for example, type of disorder by any of the other predictor variables or test result by psychological variable) contributed to a better fitting model for predicting post-test distress. This implies that the models we found fit equally well to the subjects tested for HD, FAP, and HBOC.

WHO WILL EXPERIENCE DISTRESS?

Hypotheses about the possible meaning for clinical practice

The findings of the present study support earlier observations on predicting distress after presymptomatic testing for HD. ${ }^{16}{ }^{42}$ However, in every day practice these observations can be understood and dealt with in more than one way (for example, a low score might indicate absence or denial of distress). We briefly discuss this for depression and anxiety.

Depressed participants tend to become more distressed post-test, reflected by avoidance of the intrusively experienced thoughts and feelings concerning the disorder. During pre-test counselling of a depressed participant, it is important to discuss whether it is a suitable moment for testing. Either the test might be too much to bear and testing is better suited when the depression has subsided, or the test may function as the key to set in motion the working through of emotions blocked by the continuing indecision of what to do and the continuous uncertainty about one's future. It depends on the participant what the best strategy is and sufficient time needs to be taken to find this out.

Anxious participants suffer less from intrusive thoughts and feelings after the test. Being anxious before a predictive test for one of the disorders studied is easy to understand. Taking into consideration the different implications of either test result will most probably be accompanied by a certain level of anxiety and is considered to help adaptation to the test result. Some participants, however, may be too anxious to allow their emotions to be felt. This may prevent them from thinking about the implications of either test result, which may result in inadequate adaptation in the long term. Counsellors should be trained to recognise the over-anxious in order to offer them additional support.

RECOMMENDATIONS FOR FURTHER RESEARCH This first comparative study on predictive testing for hereditary neurodegenerative and cancer syndromes is limited by the relatively small 
study populations, which makes generalisation difficult. However, the number of people formerly at risk for HD lost to follow up (32\%) is similar to that reported in previous HD studies. ${ }^{22} \mathrm{Up}$ to $44 \%$ was lost to follow up among those formerly at risk for a cancer gene. Dropouts were generally more highly educated than those continuing to participate. ${ }^{40}$ Participants with a higher education might have less need of the support provided by the follow up appointments (they had already prepared themselves thoroughly). Furthermore, we have to add that it is difficult to compare three such different patient groups.

In the present study we explored which pretest variables would have the highest predictive potential of post-test distress. An interesting question for further research would be to test whether particular variables do or do not contribute to post-test distress.

In the case of predictive testing for $\mathrm{HD}$, counselling within a multidisciplinary setting with follow up appointments is strongly recommended. ${ }^{91}$ For BRCAl testing, a similar approach is advised for evaluating the behavioural and psychosocial effects. ${ }^{92}$ We would like to stress the importance of a thorough evaluation, both by interview and other psychometric techniques, to obtain a full understanding of the psychological implications of predictive DNA testing for the growing number of disorders. One should also focus on the long term effects, as recent studies indicate that adaptation to a test result may take longer than three years. ${ }^{22}$

This study was supported by NWO grant 96010803 to the first author. The authors are very grateful to all the participants in this study and all those who assisted in data collection, interpretation, and secretarial activities.

1 The Huntington's Disease Collaborative Research Group. A novel gene containing a trinucleotide repeat that is expanded and unstable on Huntington's disease chromosomes. Cell 1993;72:971-83.

2 Brook JD, McCurrach ME, Harley HG, et al. Molecular basis of myotonic dystrophy: expansion of a trinucleotide (CTG) repeat at the 3 ' end of a transcript encoding a protein kinase family member. Cell 1992;68:799-808.

3 Bird TD. Familial Alzheimer's disease. Ann Neurol 1994;36: 335-6.

4 Haltia $M$, Viitanen $M$, Sulkava $R$, et al. Chromosome Haltia M, Viitanen M, Sulkava $R$, et al. Chromosome
14-encoded Alzheimer's disease: genetic and clinicopatho14-encoded Alzheimer's disease: genetic and clinic

5 Bakker E, van Broeckhoven C, Haan J, et al. DNA diagnosis for hereditary cerebral hemorrhage with amyloidosis (Dutch type). Am ₹ Hum Genet 1991;49:518-21.

6 Wooster R, Neuhausen SL, Mangion J, et al. Localization of a breast cancer susceptibility gene, BRCA2, to chromosome 13q12-13. Science 1994;265:2088-90.

7 Miki Y, Swensen J, Shattuck-Eidens D, et al. A strong candidate for the breast and ovarian cancer susceptibility gene BRCA1. Science 1994;266:66-71.

8 Kinzler KW, Nilbert MC, Su LK, et al. Identification of FAP locus genes from chromosome 5q21. Science 1991;253: $661-5$.

9 Groden J, Thliveris A, Samowitz W, et al. Identification and characterization of the familial adenomatous polyposis coli characterization of the familial
gene. Cell 1991;66:589-600.

10 Wijnen J, Vasen H, Khan PM, et al. Seven new mutations in HMSH2, an HNPCC gene, identified by denaturing gradient-gel electrophoresis. Am f Hum Genet 1995;56: 1060-6.

11 Wells S Jr, Chi DD, Toshima K, et al. Predictive DNA testing and prophylactic thyroidectomy in patients at risk for multiple endocrine neoplasia type 2A. Ann Surg 1994;220 237-47.

12 Almqvist $\mathrm{E}$, Bloch $\mathrm{M}$. World-wide survey on catastrophic events following predictive testing for Huntington's disease. American Society of Human Genetics meeting, San Francisco, 1996.

13 Bloch M, Adam S, Wiggins S, Huggins M, Hayden MR Predictive testing for Huntington disease in Canada: the experience of those receiving an increased risk. $A m \mathcal{F} M e d$ Genet 1992;42:499-507.
14 Codori AM, Hanson R, Brandt J. Self-selection in predictive testing for Huntington's disease. Am $\mathcal{F}$ Med Genet 1994;54 167-73.

15 Codori AM, Brandt J. Psychological costs and benefits of predictive testing for Huntington's disease. Am $\mathcal{F}$ Med Genet 1994;54:174-84

16 Decruyenaere M, Evers-Kiebooms G, Boogaerts A, et al. Prediction of psychological functioning one year after the predictive test for Huntington's disease and impact of the predictive test for Huntington's disease and impact of the 1996;33:737-43.

17 Evers-Kiebooms G, Swerts A, van den Berghe H. Partners of Huntington patients: implications of the disease and opinions about predictive testing and prenatal diagnosis. Genet Couns 1990;1:151-9.

18 Huggins $M$, Bloch $M$, Wiggins $S$, et al. Predictive testing for Huntington disease in Canada: adverse effects and unexpected results in those receiving a decreased risk. $A m$ f Med Genet 1992;42:508-15.

19 Quaid KA. Presymptomatic testing for Huntington disease in the United States. Am 7 Hum Genet 1993;53:785-7.

20 Simpson SA, Harding AE. Predictive testing for Huntington's disease: after the gene. The United Kingdom ton's disease: after the gene. The United Kingdom 1993;30:1036-8.

21 Tibben A, Frets PG, van de Kamp JJ, et al. On attitudes and appreciation 6 months after predictive DNA testing for Huntington disease in the Dutch program. Am $\mathcal{F}$ Med Genet 1993;48:103-11.

22 Tibben A, Timman R, Bannink EC, Duivenvoorden HJ 3-year follow-up after presymptomatic testing for Huntington disease in tested individuals and partners. Health Psychol 1997;16:20-35.

23 Wiggins S, Whyte P, Huggins $M$, et al. The psychological consequences of predictive testing for Huntington's consequences of predictive testing for Huntington's disease. Canadian Collaborative Study

24 Biesecker BB, Boehnke M, Calzone K, et al. Genetic counseling for families with inherited susceptibility to breast and ovarian cancer. $\mathcal{F A M A}$ 1993;269:1970-4.

25 Chaliki H, Loader S, Levenkron JC, Logan-Young W, Hall WJ, Rowley PT. Women's receptivity to testing for a genetic susceptibility to breast cancer. Am $\mathcal{F}$ Public Health 1995;85: 1133-5.

26 DudokdeWit AC, Tibben A, Frets PG, Meijers-Heijboer EJ, Niermeijer MF. Males at-risk for the BRCA1-gene, the Niermeijer MF. Males at-risk for the BRCA1-gene,
psychological impact. Psycho-Oncology 1996;5:251-7.

27 DudokdeWit AC, Tibben A, Frets PG, et al. BRCA1 in the family; a case description of the psychological interaction. Am F Med Genet 1997;71:63-71.

28 Grossfeld FJM, Lips CJM, ten Kroode HFJ, Beemer FA van Spijker HG, Brouwers-Smalbraak GJ. Psychologica consequences of DNA analysis for MEN type 2. Oncology 1996;10:141-6.

29 Kash KM, Holland JC, Halper MS, Miller DG. Psychological distress and surveillance behaviors of women with a family history of breast cancer. $\mathcal{F}$ Natl Cancer Inst 1992;84: 24-30.

30 Lerman C, Seay J, Balshem A, Audrain J. Interest in genetic testing among first-degree relatives of breast cancer testing among first-degree relatives of

31 Lerman C, Marshall J, Audrian J, Gomez-Caminero A. Genetic testing for colon cancer susceptibility: anticipated reactions of patients and challenges to providers. Int $\mathcal{f} \mathrm{Can}$ cer 1996;69:58-61.

32 Lerman C, Narod S, Schulman K, et al. BRCA1 testing in families with hereditary breast-ovarian cancer. $7 A M A$ 1996;275:1885-92.

33 Lynch HT, Watson P, Conway TA, et al. DNA screening for breast/ovarian cancer susceptibility based on linked markers. A family study. Arch Intern Med 1993;153:1979-87.

34 Petersen GM. Knowledge of the adenomatous polyposis coli gene and its clinical application. Ann Med 1994;26: coli ge

35 Petersen GM, Boyd PA. Gene tests and counseling for colorectal cancer risks: lessons from familial polyposis. Monogr $\mathcal{F}$ Natl Canc Inst 1995; 17:67-71.

36 Ponder M, Green JM. BRCAl testing: some issues in moving from research to service. Psycho-Oncology 1996;5:223 32

37 Walpole IR, Kool DA, Edkins T, et al. Genetic counseling and gene mutation analysis in familial adenomatous polyposis in Western Australia. Med F Aust 1995;162:4647.

38 Watson M, Murday V, Lloyd S, Ponder B, Averill D, Eeles $R$. Genetic testing in breast/ovarian cancer (BRCA1) families. Lancet 1995;346:583.

39 Watson M, Lloyd SM, Eeles R, et al. Psychological impact of testing (by linkage) for the BRCA1 breast cancer gene: an investigation of two families in the research setting. Psycho Oncology 1996;5:233-9.

40 DudokdeWit AC, Duivenvoorden HJ, Passchier J, Niermeijer MF, Tibben A. The course of distress experienced by people at $50 \%$ risk for an autosomal dominant inheritable disorder, participating in a predictive testing programme (submitted).

41 Tibben A, Duivenvoorden HJ, Vegter-van der Vlis $M$, et al. Presymptomatic DNA testing for Huntington disease: identifying the need for psychological intervention. $A m \mathcal{F}$ Med Genet 1993;48:137-44

42 Tibben A. What is knowledge but grieving? On psychological effects of presymptomatic DNA-testing for Huntington's disease. Thesis, Erasmus University Rotterdam, 1993. 
43 Codori AM, Slavney PR, Young C, Miglioretti DL, Brand J. Predictors of psychological adjustment to genetic testing for Huntington's disease. Health Psychol 1997;16:36-50.

44 Horowitz MJ, Wilner N, Alvarez W. Impact of Event Scale: a measure of subjective stress. Psychosom Med 1979;41:20918.

45 Schwarzwald J, Solomon Z, Weisenberg M, Mikulincer $M$. Validation of the impact of event scale for psychological sequelae of combat. $\mathcal{F}$ Cons Clin Psychol 1987;55:251-6.

46 Harper PS. Huntington's disease. London: Saunders, 1991.

47 Roos RA, Vegter-van der Vlis M, Hermans J, et al. Age at onset in Huntington's disease: effect of line of inheritance and patient's sex. F Med Genet 1991;28:515-19.

48 Jagelman $D$. The expanding spectrum of familial adenomatous polyposis. Perspect Colon Rectal Surg 1988;1:30-46.

49 Easton DF, Bishop DT, Ford D, Crockford GP. Genetic linkage analysis in familial breast and ovarian cancer: results from 214 families. The Breast Cancer Linkage Consortium. Am $\mathcal{F}$ Hum Genet 1993;52:678-701.

50 Easton DF, Ford D, Bishop DT. Breast and ovarian cancer incidence in BRCA1-mutation carriers. Breast Cancer Linkage Consortium. Am f Hum Genet 1995;56:265-7

51 Ford D, Easton DF, Bishop DT, Narod SA, Goldgar DE Risks of cancer in BRCA1-mutation carriers. Breas Cancer Linkage Consortium. Lancet 1994;343:692-5.

52 DudokdeWit AC, Tibben A, Duivenvoorden HJ, et al. Psychological distress in applicants for predictive DNA testin for autosomal dominant, heritable, late onset disorders. Med Genet 1997;34:382-90.

53 Tops CMJ. Presymptomatic DNA diagnosis of familial adenomatous polyposis. Thesis, State University Leiden, 1996.

54 Tibben A, Frets PG, van de Kamp JJ, et al. Presymptomatic DNA-testing for Huntington disease: pre-test attitudes and expectations of applicants and their partners in the Dutch experations

55 DudokdeWit AC, Tibben A, Duivenvoorden HJ, Niermeijer MF, Passchier J, Trijsburg RW. Distress in individuals facing predictive DNA-testing for autosomal dominant late-onset disorders; comparing questionnaire results with in-depth interviews. Am $\mathcal{F}$ Med Genet (in press).

56 Jong-Gierveld de J, Kamphuis FH. The development of a Rasch-type Loneliness scale. Appl Psychol Measurem 1985; 9:289-99.

57 Sarason IG, Sarason BG, Shearin EN, Pierce GR. A brief measure of social support: practical and theoretical implications. 7 Soc Pers Rel 1987;4:497-510.

58 Olson DH, Portner J, Lavee Y. FACES III- family adaptability and cohesion evaluation scales. St Paul: Family Social ity and cohesion evaluation scales. St Pat

59 Buurmeijer FA Hermans PC. Gezinsfunctioneren en individuele stoornissen. Een vergelijkend onderzoek naar het functioneren van gezinnen met en gezinnen zonder manifeste stoornissen bij een van de gezinsleden. (Family functioning and individual problems.) Thesis. Amsterdam: Swets en Zeitlinger, 1988 .

60 Zilberg NJ, Weiss DS, Horowitz MJ. Impact of Event Scale: a cross-validation study and some empirical evidence supporting a conceptual model of stress response syndromes. $\mathcal{F}$ Cons Clin Psychol 1982;50:407-14.

61 Zigmond AS, Snaith RP. The Hospital Anxiety and Depression Scale. Acta Psychiatr Scand 1983;67:361-70.

62 Spinhoven Ph, Ormel J, Sloekers PPA, Kempen GIJM, Speckens AEM, van Hemert AM. A validation study of the Hospital Anxiety and Depression Scale (HADS) in different groups of Dutch subjects. Psychol Med 1997;27: 363-70.

63 Derogatis LR, Rickels K, Roch FA. The SCL-90 and the MMPI: a step in the validation of a new self-report scale. $B r$ I Psychiatry 1976;128:280-9.

64 Arrindell WA, Ettema JHM. SCL'90. Handleiding bij een multidimensionele psychopathologie-indicator (manual). Lisse: Swets \& Zeitlinger, 1986

65 Evers A, van Vliet-Mulder JC, ter Laak J. Documentatie van tests en testresearch in Nederland. (Documentation of tests and test research in the Netherlands.) Assen: van Gorcum, 1992.

66 Beck AT, Weismann A, Lester D, Trexler L. The measurement of pessimism: the hoplessness scale. f Cons Clin Psychol 1974;42:861-5.

67 Beck AT, Steer RA. Clinical predictors of eventual suicide: a 5- to 10-year prospective study of suicide attempts. $\mathcal{F}$ Affect Dis 1989;17:203-9.
68 Beck AT, Brown G, Berchick RI, Stewart BL, Steer RA. Relationship between hopelessness and ultimate suicide: replication with psychiatric outpatients. Am $\mathcal{F}$ Psychiatry 1990;147:190-5.

69 Draper MR, Smith H. Applied regression analysis. New York Wiley, 1966

70 Cohen J, Cohen P. Applied multiple regression/correlation analysis for the behavioral sciences. 2nd ed. London Lawrence Erlbaum, 1983.

71 Brandt J, Quaid KA, Folstein SE, et al. Presymptomatic diagnosis of delayed disease with linked DNA markers. The experience in Huntington disease. $\mathscr{F} A M A 1989 ; 261: 3108$ 14.

72 Cornelis RS, Vasen HF, Meijers-Heijboer EJ, et al. Age at diagnosis as an indicator of eligibility for BRCA1 DNA testing in familial breast cancer. Hum Genet 1995;95:539 44.

73 Tibben A, Vegter-van der Vlis M, Niermeijer MF, et al. Testing for Huntington's disease with support for al parties. Lancet 1990;335:553.

74 Festinger L. A theory of cognitive dissonance. Stanford: Stanford University Press, 1957

75 Shedler J, Mayman M, Manis M. The illusion of mental health. Am Psychol 1993;48:1117-31.

76 Bonke B, Smorenburg JMJ, van der Ent CK, Spielberge $\mathrm{CD}$. Evidence of denial and item-intensity specificity in the state-trait anxiety inventory. Person Individ Diff 1987;8:18591.

77 Bloch M, Fahy M, Fox S, Hayden MR. Predictive testing fo Huntington disease. II. Demographic characteristics, lifestyle patterns, attitudes, and psychosocial assessments of the first fifty-one test candidates. Am $\mathcal{F}$ Med Genet 1989;32 217-24.

78 Shiloh S. Heuristics and biases in health decision making: their expression in genetic counseling. In: Heath $\mathrm{L}$, Tindale RS, ed. Applications of heuristics and biases to social issues. New York: Plenum Press, 1994:13-30.

79 Tibben A. Personal communication.

80 Craufurd D, Dodge A, Kerzin-Storrar L, Harris R. Uptake of presymptomatic predictive testing for Huntington's disease. Lancet 1989;2:603-5.

81 Meissen GJ, Mastromauro CA, Kiely DK, McNamara DS, Myers RH. Understanding the decision to take the predictive test for Huntington disease. Am $¥$ Med Genet 1991;39: tive test

82 Simpson SA, Besson J, Alexander D, Allan K, Johnston AW. One hundred requests for predictive testing for Huntington's disease. Clin Genet 1992;41:326-30.

83 Tibben A, Stevens $M$, de Wert GMWR, Niermeijer MF, Duijn van CM, Swieten van JC. Preparing for presymptomatic DNA testing for early onset Alzheimer's disease/ cerebral haemorrhage and hereditary Pick disease. $7 \mathrm{Med}$ Genet 1997;34:63-72.

84 Decruyenaere M, Evers-Kiebooms G, Demyttenaere K, van den Berghe $\mathrm{H}$. Predictive testing for Huntington's disease in Flanders: psychological characteristics of test applicants. Gedrag en Gezondheid 1994;22:238-47.

85 Kessler S, Bloch M. Social system responses to Huntington disease. Fam Process 1989;28:59-68.

86 McIntosh DN, Silver RC, Wortman CB. Religion's role in adjustment to a negative life event: coping with the loss of child. F Pers Soc Psychol 1993;65:812-21.

87 Alvarado KA, Templer DI, Bresler C, Thomas-Dobson S. The relationship of religious variables to death depression and death anxiety. F Clin Psychol 1995;51:202-4.

88 Atkinson BE, Malony HN. Religious maturity and psychological distress among older Christian women. Int $\mathcal{F}$ Psychol Rel 1994;4:165-79.

89 Williams DR, Larson DB, Buckler RE, et al. Religion and psychological distress in a community sample. Soc Sci Med 1991;32:1257-62

90 Janis IL, Mahl GF, Kagan J, Holt RR. Personality; dynamics, development and assessment. New York: Harcourt, Brace \& World, 1969.

91 International Huntington Association (IHA) and the World Federation of Neurology (WFN) Research Group on Huntington's Chorea. Guidelines for the molecular genetics predictive test in Huntington's disease. Neurology 1994; 44:1533-6.

92 Botkin JR, Croyle RT, Smith KR, et al. A model protocol for evaluating the behavioral and psychological effects of BRCA1 testing. F Natl Cancer Inst 1996;88:872-82. 